\title{
A 10 500-Year Sequence of Bird Remains from the Southern Boreal Forest Region of Western Canada \\ JONATHAN C. DRIVER ${ }^{1}$ and KEITH A. HOBSON ${ }^{2}$
}

(Received 4 March 1991; accepted in revised form 11 June 1991)

\begin{abstract}
The prehistoric avian fauna from the Charlie Lake Cave site, Peace River District, British Columbia, spans the last 10500 years and includes birds from eleven orders. Prior to about 10000 B.P. the fauna is sparse and the most common species is Cliff Swallow (Hirundo pyrrhonota), which probably nested at the site. The avian fauna from 10000 B.P. to the present is dominated by wetland associated birds (mainly grebes and ducks) of the same species found in the area today and is consistent with the establishment of boreal forest by 10000 B.P. From about 8000 B.P. Passenger Pigeon (Ectopistes migratorius) occurs and appears to have been a regular component of the local fauna. The assemblages demonstrate rapid colonization of boreal environments by bird populations by 10000 B.P. and probably indicate that the modern patterns of migration were established early in the Holocene.
\end{abstract}

Key words: British Columbia, fossil birds, Holocene, Passenger Pigeon

RÉSUMÉ. L'avifaune préhistorique du site de Charlie Lake Cave, dans le district de Peace River en Colombie-Britannique, couvre les 10500 dernières années et comprend des oiseaux appartenant à onze ordres différents. Antérieurement à environ $10000 \mathrm{BP}$, la faune est clairsemée et l'espèce la plus courante est l'hirondelle à front blanc (Hirundo pyrrhonota), qui nidifie probablement sur le site. L'avifaune couvrant de $10000 \mathrm{BP}$ au présent est dominée par des oiseaux associés aux terres humides (surtout des grèbes et des canards) appartenant aux mêmes espèces que l'on trouve actuellement dans la région, et cette prédominance correspond à l'établissement d'une forêt boréale d'ici $10000 \mathrm{BP}$. À partir d'environ 8000 $\mathrm{BP}$, la tourte (Ectopistes migratorius) fait son apparition et semble avoir été une composante régulière de la faune locale. Les assemblages indiquent une colonisation rapide des milieux boréaux par les populations d'oiseaux d'ici $10000 \mathrm{BP}$ et semblent indiquer que les schémas de migration actuels se sont établis au début de l'holocène.

Mots clés: Colombie-Britannique, oiseaux fossiles, holocène, tourte

Traduit pour le journal par Nésida Loyer.

\section{INTRODUCTION}

Well-preserved sub-fossil assemblages of bird bones are uncommon in Canada, mainly because assemblages of this type are usually recovered from caves and few cave sites have been excavated by paleontologists and archaeologists. This is especially true of sub-arctic and boreal regions. Open-air archaeological sites may sometimes produce large quantities of bird bone (e.g., Hobson and Driver, 1989), but most archaeological sites are dominated by species that were economically important to humans and rarely provide information about a wider range of species. Preservation of bone in open-air sites in boreal areas is usually quite poor, so there is very little evidence for the history and development of Holocene vertebrate communities in boreal regions. As a result, relatively little is known about prehistoric bird communities or the evolution of migratory routes to northern Canada and Alaska. Stratified deposits at the Charlie Lake Cave site within the boreal forest region of British Columbia span the last 10500 radiocarbon years. The deposits contain a wide variety of vertebrate fossils, including birds. This paper describes the avian assemblage at this site and attempts to use these data in paleoenvironmental reconstruction.

\section{THE CHARLIE LAKE CAVE SITE}

The Charlie Lake Cave site is located a short distance from Charlie Lake, about $7 \mathrm{~km}$ up the Alaska Highway from Fort St. John, British Columbia (56 $16^{\prime} 35^{\prime \prime} \mathrm{N}, 120^{\circ} 56^{\prime} 15^{\prime \prime} \mathrm{W}$; Fig. 1). The site was excavated in 1983, and the setting and stratigraphy of the site have been described in detail elsewhere (Driver, 1988; Fladmark et al., 1988). Although the site is named for a small cave in the sandstone escarpment that outcrops along the

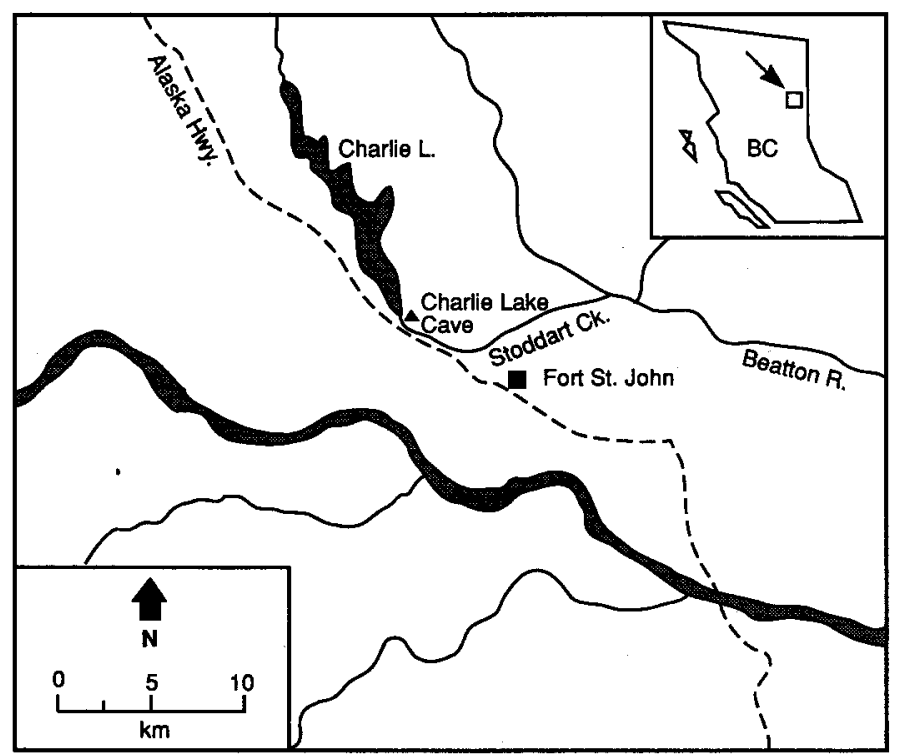

FIG. 1. Location of Charlie Lake Cave.

northeast side of Stoddart Creek, the cave itself contains only shallow deposits. Immediately in front of the cave is a deep gully that runs parallel to the escarpment containing the cave. The downslope side of this gully is formed by a large section of bedrock, which was probably detached from the bedrock escarpment in Late Pleistocene times, prior to 10500 B.P.

Since the retreat of Glacial Lake Peace from the site (probably shortly before 10500 B.P.), the gully has been filling with sediments to a depth of more than $4 \mathrm{~m}$. These sediments result from weathering of the sandstone bedrock and

\footnotetext{
${ }^{1}$ Department of Archaeology, Simon Fraser University, Burnaby, British Columbia, Canada V5A 1S6

${ }^{2}$ Department of Biology, University of Saskatchewan, Saskatoon, Saskatchewan, Canada S7N 0W0

(CThe Arctic Institute of North America
} 
down-slope movement of sediments from the hillside above the escarpment. Radiocarbon dates and observations during excavation suggest that most of these sediments have been relatively undisturbed by subsequent biological and pedogenic forces. While sediments were being added to the gully, the site was visited occasionally by humans who left stone artifacts and bones there from as early as 10500 B.P. (Fladmark et al., 1988). It was also visited by a variety of predators that brought animal bones to the site and by animals that lived and died there, creating a well-preserved and well-dated faunal assemblage (Driver, 1988). The stratigraphic sequence has been divided into four major zones, some of which can be subdivided further into sub-zones (Table 1). More detailed descriptions of the stratigraphy and chronology of the site have been presented in Driver (1988) and Fladmark et al. (1988).

TABLE 1. Summary of stratigraphic zones and sub-zones and radiocarbon dates

\begin{tabular}{lcc}
\hline \hline Zone / sub-zone & Estimated time range & Radiocarbon dates B.P. \\
\hline I & pre-10 500 B.P. & None \\
IIa & 10500 to 10000 B.P. & $10770 \pm 120$ (SFU 454) \\
& & $10450 \pm 150$ (SFU 300) \\
& & $10380 \pm 160$ (SFU 378) \\
& & $10100 \pm 210$ (RIDDL 392) \\
IIa/IIb interface & 10000 B.P. & $9990 \pm 150$ (RIDDL 393) \\
IIb & 10000 to 9000 B.P. & $9760 \pm 160$ (SFU 355) \\
IIIa & 9000 to 8100 B.P. & $7800 \pm 800$ (SFU 370) \\
IIIb & 8100 to 7000 B.P. & $8400 \pm 240$ (SFU 357) \\
& & $7100 \pm 350$ (SFU 452) \\
IIIc & 7000 to 6200 B.P. & None \\
IIId & 6200 to 5500 B.P. & $1130 \pm 240$ (SFU 453) \\
IIIe & 5500 to 4300 B.P. & $4800 \pm 640$ (SFU 451) \\
& & $4400 \pm 400$ (SFU 385) \\
IV & 4300 B.P. to present & $6700 \pm 290$ (SFU 356) \\
& & $4270 \pm 160$ (SFU 382) \\
& & $2900 \pm 400$ (SFU 358) \\
& & $1400 \pm 400$ (SFU 379) \\
\hline \hline
\end{tabular}

"These dates are inconsistent with the stratigraphy; see Driver (1988:1546).

\section{AVIAN FAUNA}

The 338 identified bird bones (Table 2) are a relatively minor component of the assemblage excavated from the site in 1983, which includes more than 3000 fish bones and more than 3000 mammal bones (Driver, 1988). The importance of bird bones in the various zones and sub-zones varies. In zone II, birds account for almost $19 \%$ of the identified specimens. In sub-zones IIIa, IIIb and IIIc the figure drops to about $8 \%$, and in sub-zones IIId and IIIe and zone IV birds form only about $3 \%$ of the fauna.

Bird bones were initially sorted by family using the comparative collection in the Zooarchaeology Laboratory, Department of Archaeology, Simon Fraser University. All bird bones were then checked further using the collection at the Royal Ontario Museum, Toronto, the Zooarchaeological Identification Centre, Ottawa, and the Burke Memorial Museum, University of Washington, Seattle.
TABLE 2. Identified avian fauna by zone and sub-zone, Charlie Lake Cave site

\begin{tabular}{|c|c|c|c|c|c|c|c|c|}
\hline \multirow[b]{2}{*}{ Taxon } & \multicolumn{8}{|c|}{ Zone/sub-zone } \\
\hline & IV & IIIe & IIId & IIIc & IIIb & IIIIa & IIb & Ila \\
\hline Podiceps auritus & & & & 1 & 3 & 3 & 15 & \\
\hline Aechmophorus sp. & 20 & & & 1 & 2 & 5 & 2 & \\
\hline Medium-sized grebes & 2 & 2 & 1 & 2 & 9 & 3 & 4 & \\
\hline Phalacrocorax auritus & 1 & & & & & & & \\
\hline Cygnini & 1 & & & & & & & \\
\hline Anserini & 2 & & & & & & & \\
\hline Anatini & 36 & 4 & 5 & & 2 & & 2 & 1 \\
\hline Anas crecca & 13 & & 2 & & 1 & 9 & 1 & \\
\hline Anas platyrhynchos & 1 & & & & & & 1 & \\
\hline Aythyini & 1 & 1 & & & & & & \\
\hline Melanitta fusca & 1 & & & & & & & \\
\hline Bucephela sp. & 1 & & & & & & & \\
\hline Mergus sp. & 1 & 1 & 1 & & & & & \\
\hline Lophodytes cucullatus & 1 & & & & & & & \\
\hline Oxyura jamaicensis & 2 & & & & & & 1 & \\
\hline Falconiformes & & & 1 & & & & & \\
\hline Tetraoninae & 18 & 3 & 4 & & 10 & 8 & 13 & \\
\hline Small Rail & & & & & & & 2 & \\
\hline Fulica americana & & 1 & & & & & 10 & \\
\hline Calidris minutilla & 1 & & & & & & & \\
\hline Calidris sp. & & & & & & 4 & & \\
\hline Small wader & 1 & & & & & & & 2 \\
\hline Larus sp. & 2 & & & 1 & & & & \\
\hline Ectopistes migratorius & 5 & & 1 & & 2 & 1 & & \\
\hline Strigiformes & 3 & & & & & 1 & & \\
\hline Asio flammeus & & & & & & & 8 & \\
\hline Surnia ulula & & & & 5 & & & & \\
\hline Ceryle alcyon & & 1 & & & & & & \\
\hline Passeriformes & 19 & 2 & 4 & & 1 & 1 & 1 & 11 \\
\hline Hirundo pyrrhonota & & & & & & 1 & 3 & 16 \\
\hline Corvus corax & & & & & 1 & & & \\
\hline Total & 134 & 15 & 19 & 10 & 31 & 36 & 63 & 30 \\
\hline
\end{tabular}

\section{SYSTEMATIC DESCRIPTIONS}

Avian remains are summarized below by order. Where possible we have included reference to the current status of species in the vicinity of Charlie Lake Cave. Unless stated otherwise, our analyses are based on information provided by Campbell et al. (1990).

Podicipediformes: With the exception of the earliest deposits (sub-zone IIa), grebes occurred throughout the sequence. Due to its greater size, Aechmophorus sp. was readily separated from other grebes. Although long considered as two colour phases of a single species, the Western Grebe $(A$. occidentalis) is now considered a separate species from Clark's Grebe (A. clarkii). There appear to be no osteological differences between the two species, which may have separated relatively recently. For this reason, an earlier identification of A. occidentalis for the large grebes (Driver, 1988) must be replaced by Aechmophorus sp. Approximately half of the remaining grebe bones were identifiable as Horned Grebe (Podiceps auritus). Presently Horned Grebes breed throughout this boreal ecozone. No breeding records exist for Western 
Grebes here, but the area is coincident with the northernmost limit of inland occurrence of the species in British Columbia.

Pelecaniformes: Three cormorant bones were recovered from the most recent deposits (zone IV) and one of these was identified as Double-Crested Cormorant (Phalacrocorax auri$t u s)$. The other bones were almost certainly of this species, since it is the only North American cormorant that regularly occurs inland. This species breeds on the southwest coast of Alaska (Godfrey, 1986). Northernmost breeding records in Canada are for northern Alberta at the southern edge of the boreal forest (Godfrey, 1986). In British Columbia nesting records occur only on the southwest coast, but the species has been recorded in the Charlie Lake region. Coastal records date to the last 5000 years (Hobson and Driver, 1989) and are coincident with the period of occurrence at Charlie Lake.

Anseriformes: A single swan bone was recovered from zone IV but could not be identified to species. Currently, both Tundra (Cygnus columbianus) and Trumpeter (C. buccinator) swans occur in this area. Tundra Swans use the Fort St. John region as a stopover site while migrating to and from Alaskan breeding grounds. Trumpeter Swans breed in the Peace lowlands and boreal forest but also use the Charlie Lake area as a stopover site en route to Alaska.

Two goose bones were identified in zone IV but could not be identified to genus or species. Duck bones were common in most zones, but species identification was difficult because of considerable overlap in bone size and morphology within this group. The most commonly identified species was the Greenwinged Teal (Anas crecca), probably because its small size makes its bones distinctive. Currently this species breeds throughout the boreal and sub-arctic regions of Canada. A similar distribution is found for the Mallard (Anas platyrhynchos), for which two bones were identified. One Goldeneye (either Bucephela clangula or B. islandica) and one Whitewinged Scoter (Melanitta fusca) were found in zone IV. Both species of Goldeneye and the White-winged Scoter currently breed throughout northern British Columbia. Bones of Ruddy Duck (Oxyura jamaicensis) were found in zone IV and in subzone IIb. This species breeds in the Peace River area but also breeds locally farther north to the southern Northwest Territories. At least two mergansers were present in the upper zones. A large species (either Mergus merganser or M. serrator) was represented by three bones. Red-breasted Mergansers breed only in northwestern British Columbia but occur throughout the province. Common Mergansers have a more widespread breeding distribution in British Columbia and are known to nest in the Charlie Lake area. A single specimen of Hooded Merganser (Lophodytes cucullatus) was recovered from zone IV. This species is uncommon in the area today and typically breeds farther south in central British Columbia and southwestern Alberta.

Falconiformes: A single Falconiform bone was recovered in zone IIId but could not be identified to genus.

Galliformes: Grouse and ptarmigan (Tetraoninae) bones were a constant component of the fauna from sub-zone IIb onwards but identification to genus was not possible. Currently, ptarmigan (Lagopus spp.) occur mainly west of the Peace River region, but grouse are more common. Ruffed Grouse (Bonasa umbellus) occur primarily in forested areas of the region, whereas Sharp-tailed Grouse (Tympanuchus phasianellus) occur in more open areas of the Peace lowlands.

Gruiformes: Two small rail bones were recovered from sub-zone IIb. On the basis of size and morphology the bones are most similar to either Sora (Porzana carolina) or Virginia Rail (Rallus limicola). Today only the Sora is found in the Peace River region, and the Virginia Rail occurs only in the southern part of the province. However, this species does breed in northeast and central Alberta. Bones of the American Coot (Fulica americana) were a conspicuous component of sub-zone IIb. Coots breed at Charlie Lake today and range as far north as the southeast Yukon.

Charadriiformes: Three small gull bones were recovered. These were comparable to Franklin's Gull (Larus pipixcan) and Bonaparte's Gull (L. philadelphia), both of which can be found in the area today. A number of small wader bones were recovered. These include one specimen of Least Sandpiper (Calidris minutilla) and a number of other specimens assignable to Calidris sp. Many species of sandpiper pass through the Peace River region during their migrations to and from the northern breeding areas.

Columbiformes: It is believed that Passenger Pigeons (Ectopistes migratorius) occurred primarily in the eastern half of North America from central and southern Canada to Louisiana and Florida and wintered south of their breeding range (Goodwin, 1977:204). With the exception of the introduced Rock Dove (Columba livia), pigeons are currently absent from the Peace River area. Nine columbid bones were positively identified as Passenger Pigeon (Fig. 2). The earliest occurrence is in sub-zone IIIa, estimated to date from 9000 to 8100 B.P. (Table 1). This is the earliest fossil record for Passenger Pigeon in British Columbia, although specimens have been recorded from a number of Late Pleistocene locations in other areas of North America (Lundelius et al., 1983).

Passenger Pigeons are currently regarded as having been casual and accidental in British Columbia (AOU, 1983), and Bent (1932:400) states that "Passenger Pigeon also have been recorded from British Columbia, but the evidence seems rather unsatisfactory." However, their occurrence in the faunal assemblages of four distinct stratigraphic zones suggests that they may have been migrating regularly to the area during the summer. A recent study of the Passenger Pigeon in the eastern woodlands of North America has shown that even in areas where the birds were known to be abundant during the 19th century, some prehistoric archaeological sites contain relatively few bones (Neumann, 1985). Neumann suggested that the immense populations of Passenger Pigeon recorded during the 19 th century were largely the result of the alteration of the landscape through the introduction of European farming methods, which created a habitat highly favourable to Passenger Pigeons and which reduced the numbers of competitors for their major foods.

Prehistoric archaeological sites in the northeastern United States often exhibit relatively low percentages of Passenger Pigeon, even though the sites lie within the breeding area of the birds. Neumann (1985) ascribes these low percentages to the much smaller pigeon populations in the centuries prior to European incursions.

At Charlie Lake, Passenger Pigeons constitute about $3 \%$ of the total avian fauna. At the early 19 th-century Fort d'Epinette, about $50 \mathrm{~km}$ southeast of Charlie Lake, Passenger Pigeon also accounted for $3 \%$ of the bird remains identified to at least the order (Williams, 1978). These values are higher than at some archaeological sites in the regions considered as prime Passenger Pigeon habitat in eastern North America. The occurrence of Passenger Pigeons at the only two sites in the Peace River District where fauna has been comprehensively 


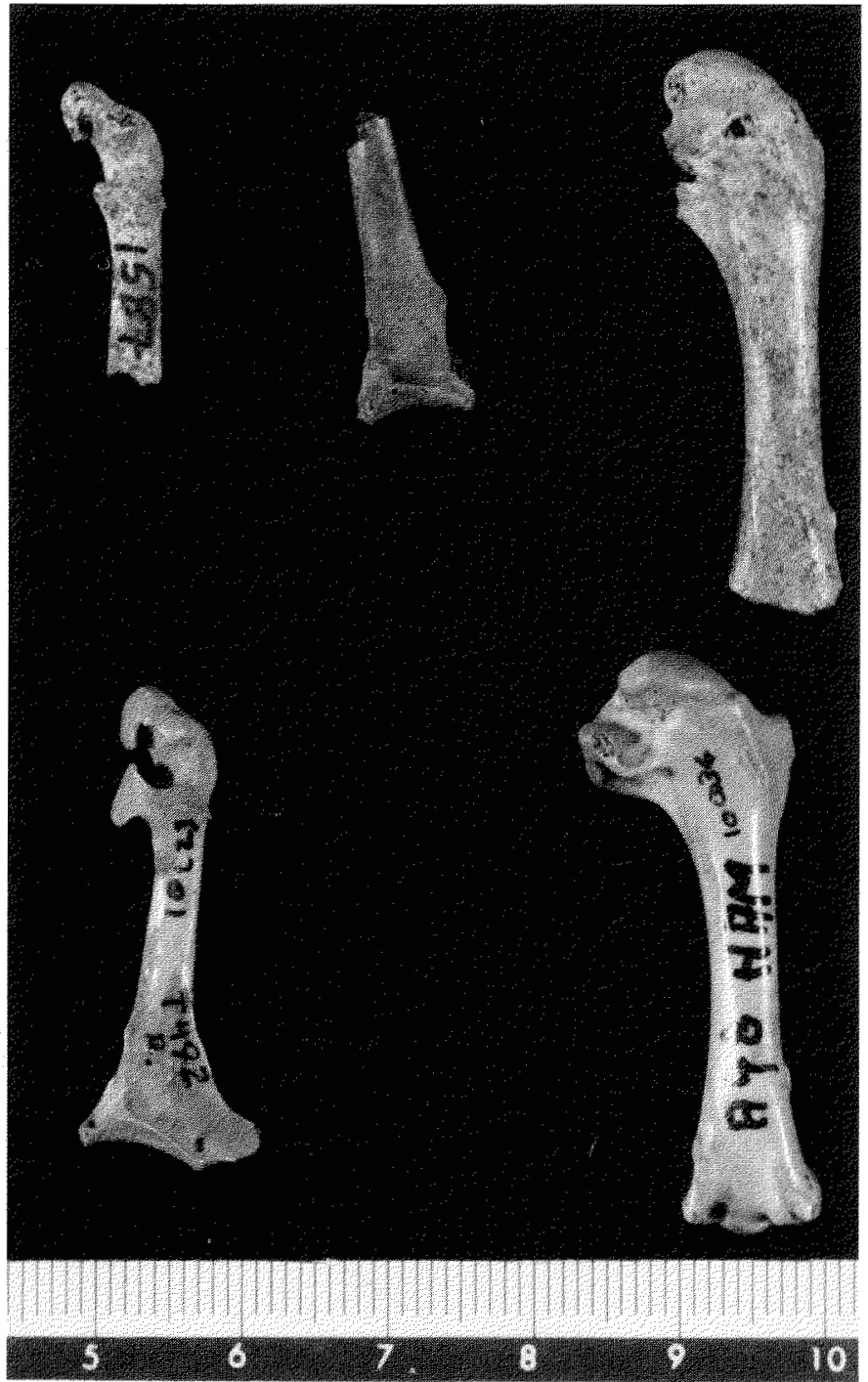

FIG. 2. Specimens of Passenger Pigeon. Top: two coracoids and a humerus from Charlie Lake Cave. Bottom: coracoid and humerus from late prehistoric sites in Ontario.

studied, coupled with their regular appearance in faunal assemblages from at least 8000 B.P., suggests that Passenger Pigeon was a relatively common summer visitor to the area.

There are similarly limited data from Alberta to support this conclusion. About $6 \%$ of the identified bird bones from the historic period site of Fort George in east-central Alberta were from Passenger Pigeon (McCorquodale, 1971; Smith and Kidd, 1971) and a single bone was identified from Fort White Earth, also in east-central Alberta (Hurlburt, 1977).

Strigiformes: A few large owl bones were identified, but genus could not be determined. An articulated foot of Shorteared Owl (Asio flammeus) was recovered from just above the interface between sub-zones IIa and IIb and probably dates shortly after 10000 B.P. This species currently breeds throughout boreal and sub-arctic regions of Canada and Alaska. Bones of Northern Hawk-owl (Surnia ulula) were recovered from sub-zone IIIc, dating between about 7000 and 5000 B.P. Today this species is distributed throughout the boreal regions of North America.

Coraciiformes: A single bone of Belted Kingfisher (Ceryle alcyon) was recovered from sub-zone IIIe (5000 B.P.). This species breeds from western Alaska and throughout much of forested Canada.

Passeriformes: Bones of this very diverse order are difficult to identify to species, and the dearth of species represented is partly due to difficulties of identification. The most striking occurrence is the presence of numerous bones of Cliff Swallow (Hirundo pyrrhonota) in the lower deposits, mainly sub-zone IIa (10 500 to 10000 B.P.). The rocky gully at the Charlie Lake Cave site would have provided a suitable nesting area for this species, which today nests a few metres above ground level in similar sandstone cliffs along Charlie Lake. Examination of deposits under modern Cliff Swallow communities shows that small middens build up, composed of droppings, decayed nests and dead birds. It is likely that the strong representation of Cliff Swallows in the earliest fauna records the presence of a colony of these birds, to our knowledge the oldest colony of this species recorded in Canada. Most of the other passerine bones from sub-zone IIa are probably from this species.

Other passerines recorded include a single bone of Common Raven (Corvus corax). Driver (1988) reported a specimen of Barn Swallow (Hirundo rustica), but re-examination of the specimen does not support the original identification and it has been included in the Passeriformes category.

\section{TAPHONOMY AND PALEOECOLOGY}

Generally, avian remains are considered poor paleoecological indicators because they are often difficult to identify to species and because birds may migrate long distances and are thus not restricted to local habitats. Furthermore, the presence of unexpected species at a particular locality can be ascribed to unusual short-term weather conditions, such as storms (e.g., Wilson, 1978). There are also more general problems with deducing past environments from vertebrate remains. Many of these have been summarized by Grayson (1981) and include problems of taphonomy, disturbance and quantification procedures. Grayson (1981) notes that one can either use presence/ absence of a species or consider its relative frequency in an assemblage as an index of its importance.

Presence/absence is problematic because it gives equal weight to species represented by single bones and thousands of bones. Paleoecological reconstructions based on presence/ absence are susceptible to errors introduced by mixing of assemblages by a variety of factors (e.g., redeposited fauna, rodent burrowing, etc.). On the other hand, the use of relative frequencies may exaggerate the importance of animals with bones that are easy to identify or animals that died on site and were left as complete skeletons. In this study we have relied mainly on presence/absence data because of the relatively small sample size and because we do not have a good understanding of the taphonomic history of most of the species identified.

All paleoecological studies using species as indicators of past environments must take into account the taphonomic history of the bones. For smaller mammals and birds it is particularly important to remember that a wide variety of predators may deposit bones and that the structure of the faunal assemblage may reflect as much on the type of predator as upon the local environment. Some of the bird bones at the Charlie Lake Cave site were probably introduced by avian and mammalian predators. The presence of sandstone cliffs in a forested setting would have been attractive to hawks and owls for nesting, 
roosting and feeding. The cave itself may have been an attractive den for carnivores. Avian predators are not well represented in the faunal assemblage, but this is not surprising as one would not necessarily expect owls and hawks to die at roosting sites, and one would expect bones of prey to outnumber bones of predators. Mammalian predators found at the site include virtually every modern carnivore in the Peace River district (Driver, 1988). Most of these date from the period of zone IV deposition, when the cave (a suitable denning site) would have been more accessible as the gully in front of it filled with sediment. Although mammalian predators are numerous, they were probably not responsible for introducing most of the bird bones. Many of the preserved bird bones are too large to have passed through a carnivore's digestive system, and they lack the heavy erosion caused by mammalian digestive processes. They are more similar in terms of size, breakage and erosion to the remains left by large owls (Kusmer, 1986). Moreover, some specimens were found as partially articulated units, suggesting deposition as pellets or as discarded, defleshed carcass portions.

Other bird bones were probably deposited as a result of natural deaths at the site. As was suggested above, Cave Swallows probably nested at the site, and the high frequency of this species in zone II is probably the result of natural deaths. Many of the bones are unbroken, which further supports this interpretation.

People were certainly contributing some bones to the faunal assemblages (Fladmark et al., 1988), but there are problems assessing which bird species were humanly introduced. Ericson (1987) noted two criteria that definitely denote human involvement in the deposition of bird bones: modification of bones as a result of butchery, cooking, etc., or introduction of species not native to the region. No bird bones from the Charlie Lake Cave site exhibit evidence for butchery in the form of cut marks. Approximately $9.4 \%$ of all bird bones are burnt, which compares to $10 \%$ of the total fauna from the site. However, burning cannot be associated exlusively with human activity at this site. No bird bones exhibited the distinctive patterned burning associated with roasting (Vigne and MarinvalVigne, 1983).

Ericson (1987) also discussed variation in the relative frequency of different areas of the bird skeleton as a possible indicator of human involvement in the accumulation of avian bones. Ericson studied natural and cultural accumulations of avian bones from predominantly coastal sites in northwestern Europe. Ericson's study showed that naturally deposited avian bones in coastal environments show over-representation of wing bones, while humanly accumulated domestic fowl faunas exhibit an under-representation of wing bones (Ericson, 1987:73). Unfortunately, Ericson's study is of limited value in evaluating avian assemblages in general. First, Ericson almost completely ignores widespread ethnographic data concerning the use of birds by humans for non-food purposes (e.g., decorative uses of feathers and talons). Second, Ericson assumes that domestic fowl provide a suitable model for the treatment of all birds used for food. This is an unwarranted assumption, especially as domestic fowl have heavily muscled legs, while in some wild birds the greatest amount of available meat is often associated with flight muscles of the wings and pectoral girdle. Livingston (1989) has suggested that element frequency may relate to the relative robustness of different areas of avian skeletons and has pointed out that the survivorship of anterior and posterior limbs may depend upon the locomotory adaptations of the taxa involved, so that relative frequencies of wing bones need not necessarily be a criterion of human or non-human accumulations.

In the absence of good criteria for distinguishing humanly accumulated bird bones from naturally accumulated bones, detailed discussion of element frequencies are not presented in this paper. However, note should be made of unusual element frequencies for owl bones, which suggest that they were humanly collected. Owls are represented by 17 specimens: a tarsometatarsus, 15 phalanges, and a premaxilla. This suggests deliberate selection of beaks and talons, a common pattern of human selection for raptor and owl body parts.

The Charlie Lake avian assemblages are dominated by species associated with freshwater environments. From zone IIb until the present there are fairly consistent assemblages of birds, which suggest the local presence of freshwater lakes and marshes. Grebes and ducks, as well as less common species, demonstrate the presence of open water from about 10000 B.P. to the present. This fits well with the modern local environment, which includes a fairly large lake and associated wetlands.

Analysis of paleoenvironments in the area using geomorphology (Mathews, 1978, 1980), mammals (Churcher and Wilson, 1979; Driver, 1988) and palynology (MacDonald, 1987) provides further insight into environmental change. The final stages of deglaciation are poorly dated, but ice was absent from this part of the Peace River before 11000 B.P. Large ice-dammed lakes dominated much of the lower-lying areas, and the site may have been covered by Glacial Lake Peace prior to 10500 B.P. The vegetation of the region from 11000 to 10000 B.P. was an open grassland with patches of deciduous woodland (Churcher and Wilson, 1979; Driver, 1988; MacDonald, 1987). The avian fauna from sub-zone IIa is very sparse but is consistent with the environment reconstructed from the above data. The virtual absence of waterbirds, especially ducks, suggests that the glacial lakes may have been relatively unproductive environments and were not suitable for colonization by waterfowl.

By about 10000 B.P. environments in the Peace River area underwent a major change as boreal forests colonized much of the landscape (MacDonald, 1987). Open habitats were replaced rapidly by boreal forest. This is reflected in the Charlie Lake mammal fauna (Driver, 1988). The bird remains after 10000 B.P. essentially record the development of modern conditions. While the fauna is heavily biased towards waterbirds, it is consistent with modern avian faunas in the area today. It appears that once stable drainage systems and boreal forest were established in the Peace River District an essentially modern avifauna was present. Many of the species found in the Charlie Lake Cave site are migratory, which suggests that major migration patterns were established early in the Holocene. The presence of Passenger Pigeon from at least 8000 years ago demonstrates that this species was a regular component of the British Columbia bird community and that its range was not determined solely by the distribution of eastern deciduous forests.

\section{ACKNOWLEDGEMENTS}

Excavations at Charlie Lake Cave were funded by a SSHRCC grant to Knut Fladmark. Analysis of the fauna was funded by a SSHRCC grant to Driver. The following people kindly allowed access to comparative collections: Howard Savage (Toronto); Sievert 
Rohwer, Terri Smith, Chris Wood (Seattle); Darlene Balkwill (Ottawa). Howard Savage also made a permanent loan of specimens of Passenger Pigeon to the Zooarchaeology Laboratory, SFU. Photographs and figures were prepared by the Instructional Media Centre, SFU. We thank an anonymous reviewer, W.A. Montevecchi and M.C. Wilson for their constructive and informative comments on the paper.

\section{REFERENCES}

AMERICAN ORNITHOLOGISTS' UNION (AOU). 1983. Check-list of North American birds. 6th edition. Lawrence, Kansas: American Ornithologists' Union.

BENT, A.C. 1932. Life histories of North American Gallinaceous birds: Orders Galliformes and Columbiformes. Washington, D.C.: Smithsonian Institution Bulletin 162.

CAMPBELL, R.W., DAWE, N.K., McTAGGART-COWAN, I., COOPER, J.M., KAISER, G.W., and McNALL, M.C.E. 1990. Birds of British Columbia. Victoria: Royal British Columbia Museum.

CHURCHER, C.S., and WILSON, M. 1979. Quaternary mammals from the Peace River District, Alberta. Journal of Paleontology 53:71-76.

DRIVER, J.C. 1988. Late Pleistocene and Holocene vertebrates and palaeoenvironments from Charlie Lake Cave, northeast British Columbia. Canadian Journal of Earth Sciences 25:1545-1553.

ERICSON, P.G.P. 1987. Interpretations of archaeological bird remains: a taphonomic approach. Journal of Archaeological Science 14:65-75.

FLADMARK, K.R., DRIVER, J.C., and ALEXANDER, D. 1988. The Paleoindian component at Charlie Lake Cave (HbRf 39), British Columbia. American Antiquity 53(2):371-384.

GODFREY, W.E. 1986. Birds of Canada. Ottawa: National Museum of Canada.

GOODWIN, D. 1977. Pigeons and doves of the world. Ithaca: Cornell University Press.

GRAYSON, D.K. 1981. A critical view of the use of archaeological vertebrates in paleoecological reconstructions. Journal of Ethnobiology 1:28-38.

HOBSON, K.A., and DRIVER, J.C. 1989. Archaeological evidence for use of Strait of Georgia by marine birds. In: Vermeer, K., and Butler, R.W., eds. The ecology and status of marine birds in the Strait of Georgia, British Columbia. Ottawa: Canadian Wildlife Service Special Publication. 168-173.

HURLBURT, I. 1977. Faunal remains from Fort White Earth, N.W.Co (1810-1813). Edmonton: Provincial Museum of Alberta Human History Occasional Paper No. 1.
KUSMER, K.D. 1986. Microvertebrate taphonomy in archaeological sites: An examination of owl deposition and the taphonomy of small mammals from Sentinel Cave, Oregon. M.A. thesis, Department of Archaeology, Simon Fraser University, Burnaby, British Columbia.

LIVINGSTON, S.D. 1989. The taphonomic interpretation of avian skeletal part frequencies. Journal of Archaeological Science 16:537-547.

LUNDELIUS, E.L., Jr., GRAHAM, R.W., ANDERSON, E., GUILDAY, J., HOLMAN, J.A., STEADMAN D.W., and WEBB, S.D. 1983. Terrestrial vertebrate faunas. In: Porter, S.C., ed. Late-Quaternary environments of the United States. Vol. 1, The Late Pleistocene. Minneapolis: University of Minnesota Press. 311-353.

MacDONALD, G.M. 1987. Postglacial development of the subalpine-boreal transition forest of western Canada. Journal of Ecology 75:303-320.

MATHEWS, W.H. 1978. Quaternary stratigraphy and geomorphology of Charlie Lake (94A) map area, British Columbia. Geological Survey of Canada Paper 76-20.

.1980. Retreat of the last ice sheets in northeastern British Columbia and adjacent Alberta. Geological Survey of Canada Bulletin 331.

McCORQUODALE, B.A. 1971. Identification of faunal remains from the Fort George site. In: Kidd, R.S. Fort George and the early fur trade in Alberta. Edmonton: Provincial Museum and Archives of Alberta Publication No. 2. 233-235.

NEUMANN, T.W. 1985. Human-wildlife competition and the Passenger Pigeon: Population growth from system destabilization. Human Ecology 13(4):389-410.

SMITH, H.C., and KIDD, R.S. 1971. A record of the Passenger Pigeon in Alberta. Canadian Field Naturalist 85(3):259.

VIGNE, J.-D., and MARINVAL-VIGNE, M.-C. 1983. Methode pour la mise en evidence de la consommation du petit Gibier. In: Clutton-Brock, J., and Grigson, C., eds. Animals and archaeology 1: Hunters and their prey. Oxford: British Archaeological Reports International Series 163. 239-242.

WILLIAMS, J.H. 1978. Fort d'Epinette: A description of faunal remains from an early fur trade site in northern British Columbia. M.A. thesis, Department of Archaeology, Simon Fraser University, Burnaby, British Columbia.

WILSON, M. 1978. Cyclones, coconuts and chickens across the sea: Dispersal theory and cultural diffusion. In: Duke, P.G., Ebert, J., Langemann, G., and Buchner, A.P. Diffusion and migration: Their roles in cultural development. Calgary: University of Calgary Archaeological Association. $65-105$. 